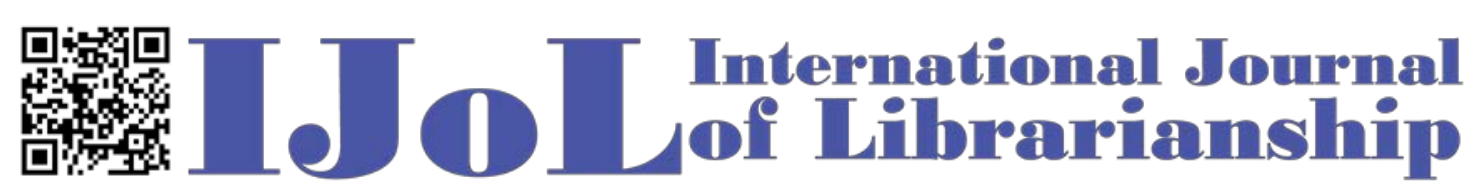

ISSN: 2474-3542 Journal homepage: http://journal.calaijol.org

\title{
A Study of the Information Literacy Needs of Social Work Graduate Students at a mid-sized Canadian university
}

Jelena Magliaro and Sharon Munro

\begin{abstract}
:
This study consists of an analysis of the information literacy (IL) needs and levels of 44 social work graduate students at a mid-sized Canadian university using the Technology Acceptance Model. Students completed a quantitative questionnaire that included supplementary open-ended questions. Results showed that students who received a library tour and/or in-class library instruction were more knowledgeable and confident about library resources and services. The study clearly demonstrates that information literacy sessions should be essential components of graduate education. A comprehensive literature review of information literacy studies focusing on social work students is also provided, along with the current graduate social work modified Beile Test of Information Literacy for Education (B-TILED) assessment tool (Beile O’Neil, 2005). The authors recommend that information literacy surveys in Canada include the relevant required elements for the Institutional Quality Assurance Process (IQAP) and program learning outcomes. Given the lack of a Canadian national document for information literacy standards, such surveys should also reflect the components of ACRL's new Framework for Information Literacy for Higher Education. This study can serve as a model for replication at other universities, particularly those that are part of the Ontario Council of University Libraries and that have graduate social work programs.
\end{abstract}

To cite this article:

Magliaro, J., \& Munro, S. (2018). A study of the information literacy needs of social work graduate students at a mid-sized Canadian university. International Journal of Librarianship, 3(2), 3-35.

To submit your article to this journal:

Go to http://ojs.calaijol.org/index.php/ijol/about/submissions 


\title{
A Study of the Information Literacy Needs of Social Work Graduate Students at a mid-sized Canadian university
}

\author{
Jelena Magliaro and Sharon Munro \\ University of Windsor, Windsor, ON, Canada
}

\begin{abstract}
This study consists of an analysis of the information literacy (IL) needs and levels of 44 social work graduate students at a mid-sized Canadian university using the Technology Acceptance Model. Students completed a quantitative questionnaire that included supplementary open-ended questions. Results showed that students who received a library tour and/or in-class library instruction were more knowledgeable and confident about library resources and services. The study clearly demonstrates that information literacy sessions should be essential components of graduate education. A comprehensive literature review of information literacy studies focusing on social work students is also provided, along with the current graduate social work modified Beile Test of Information Literacy for Education (B-TILED) assessment tool (Beile O’Neil, 2005). The authors recommend that information literacy surveys in Canada include the relevant required elements for the Institutional Quality Assurance Process (IQAP) and program learning outcomes. Given the lack of a Canadian national document for information literacy standards, such surveys should also reflect the components of ACRL's new Framework for Information Literacy for Higher Education. This study can serve as a model for replication at other universities, particularly those that are part of the Ontario Council of University Libraries and that have graduate social work programs.
\end{abstract}

Keywords: information literacy, social work graduate students, library instruction, embedded librarianship; liaison roles; B-TILED

\section{INTRODUCTION}

The academic library is the gateway to a wide range of resources for students and faculty. There can be an overwhelming number of choices. The increasing emphasis on evidence-based practice in social work makes the acquisition of information literacy (IL) skills and abilities even more important for students, faculty and practitioners. In addition, changing standards for reviews of undergraduate and graduate programs mean that analysis and evaluation of programs, services and resources are now required rather than just descriptions of the same. The academic library must also reflect the values and meet the goals of its home institution and, in partnership with faculty, 
make information literacy an integral part of the curriculum and accreditation processes on campus. This is particularly important for Canadian university accreditation schemes as few authors have examined the role of information literacy in institution-wide accreditation practices (Bradley, 2013).

\section{INFORMATION LITERACY STANDARDS}

In 2000, the Association of College and Research Libraries (ACRL) Standards Committee and the ACRL Board of Directors reviewed and approved Information Literacy Standards for Higher Education. These Standards provided a definition for what constituted an information literate individual. Much has changed since these Standards were originally devised and ACRL has now developed a Framework for Information Literacy for Higher Education. Within this framework, information literacy is defined as:“...the set of integrated abilities encompassing the reflective discovery of information, the understanding of how information is produced and valued, and the use of information in creating new knowledge and participating ethically in communities of learning.” (Association of College and Research Libraries [ACRL], 2015, Introduction for Faculty and Administrators, para.1).

One of the major underpinnings of the new framework is collaboration among librarians, faculty and students and all of the many benefits that this entails for information literacy. The framework contains six frames consisting of: Authority is Constructed and Contextual; Information Creation as a Process; Information has Value; Research as Inquiry; Scholarship as Conversation; and Searching as Strategic Exploration (ACRL, 2015). Information literacy is viewed through these frames, “...each of which includes a concept central to information literacy, knowledge practices, and dispositions” (ACRL, 2015, Appendix 1: Implementing the framework, para.2). Students need to master the concepts and knowledge in each of the frames in order to gain expertise in their disciplines or professions (ACRL, 2015). The Framework is based on the concept of metaliteracy with information literacy seen as “...an overarching set of abilities in which students are consumers and creators of information who can participate successfully in collaborative spaces” (ACRL, 2015, Introduction, para.4). It reflects the new realities of today's complex information environment by putting more emphasis on electronic resources; by accommodating a variety of learning styles and models; and by incorporating new realities such as blended learning and the flipped classroom (ACRL, 2015).

Saunders (2017) analyses the new framework from a social justice perspective and gives an overview of some of the reactions to it, both positive and negative. She also provides insight into the efforts made by ACRL to include social justice and anti-oppression perspectives and practices in the framework. However, she believes that more needs to be done and offers her own framework entitled "Information Social Justice" for consideration and discussion. She notes in the definition for her proposed framework:

Information is created within existing power structures, and those power structures can impact the production and dissemination of information, as well as distort, suppress, or misrepresent information. To understand and use information most effectively, users must be able to examine and interrogate the power structures that impact that information, and analyze the ways that information can be used to both inform and misinform (p. 67). 
The increased emphasis on social justice and anti-oppression practices in information literacy theory, standards and practices, fits well with social work.

As noted in the new ACRL framework, successful information literacy programs require collaboration between librarians, course instructors and students and an understanding of the objectives, goals and outcomes of such programs by all involved. Gullikson (2006) found that not much had been written about the views and reactions of faculty to the original ACRL Standards in the library literature (p. 584). She conducted a study of faculty perceptions of the Standards at four Canadian universities. She found that some faculty viewed the language used in the Standards for information literacy outcomes as confusing or repetitive. Faculty were also more likely to be in agreement about expected information literacy outcomes for students prior to or in the first year of university than for other years. Gullikson (2006) recommended that further research be done to identify the information literacy outcomes that were of the most or least importance to faculty (p. 591).

Catalano (2010) describes a study that was undertaken to assess the information literacy skills and knowledge of graduate Education students at Hofstra University using the ACRL Standards. She notes that program accreditation is making standards-based information literacy skills increasingly important (p. 21). The study showed that the students were more skilled at evaluating information sources than anticipated but did need “...advanced bibliographic search skills and strategies that are often not addressed in traditional "one-shot” library instruction sessions” (p. 31). Catalano recommends multiple information literacy sessions or a one-credit course for graduate students throughout the program in order to meet their needs (p. 31).

Gordon and Bartoli (2012) discuss the collaborative efforts of a librarian and faculty member to integrate information literacy into a graduate counseling psychology program. Instead of using the ACRL Standards, they chose to use "discipline-based standards" from the Association of Counselor Education and Supervision (ACES) for their instructional goals (p. 23). By so doing, they hoped to emphasize the relevance of information literacy goals and skills to the workplace as well as to faculty and administrators. They found that this approach had much more appeal to faculty members and students and made them more aware of the relevance of information literacy for specific courses and disciplines (p. 37).

\section{INFORMATION LITERACY AND ACCREDITATION}

Information literacy should be an integral part of academic programs and their accreditation processes, but this is not necessarily the case. Bradley (2013) discovered that little had been written about information literacy in relation to accreditation standards for various professions. She conducted a study of accreditation standards for three professions - social work, nursing and engineering - and looked for references to information literacy in the standards (p. 44). She found that the standards for professional programs for the UK and Australia paralleled the original ACRL Information Literacy Competency Standards more closely than was the case for Canada and the United States. Bradley believes that this is partly due to the absence of a national document for information literacy standards/guidelines in Canada, whereas the United Kingdom, Australia and the United States all have such documents (p. 63). However, she notes that this does not explain why the ACRL Competency Standards have not become a more integral part of accreditation processes in Canada (p. 64). She believes that the accreditation process is a prime opportunity for 
librarians to demonstrate their value to programs and that they should play an active part in this process. She recommends that librarians and their professional associations become more involved with revising and integrating IL-related outcomes into accreditation standards for professional programs. She also holds that the reverse is true and that consideration should be given to including professionals and academics who are not librarians in the revision process of information literacy-related standards for librarians (p. 65).

\section{SOCIAL WORK AND EVIDENCE-BASED PRACTICE}

Evidence-based practice has brought a new tenor to social work practice, making research an integral part of clinical work. Gibbs and Gambrill (2002) describe it as “...the conscientious, explicit and judicious use of current best evidence in making decisions about the care of clients" (p. 452). They note that "EBP is designed to create professionals who are lifelong learners who draw on practice-related research findings and involve clients as informed participants in decisions made” (p. 452). Lewis (2003) emphasizes the importance of social work research for policy and practice (p. 579), noting that the profession needs “...critically reflective social workers” who will “...develop and demonstrate the same sorts of skills and values that research in our field demands" (p. 585).

Not everyone is a proponent of evidence-based practice. Poole (2010) advocates for antioppressive and critical social work practices and worries about “...interests that welcome evidence-based and other modernist inventions meant to limit, control and prescribe” (p. 8). Herz and Johansson (2011) are concerned that the move towards evidence-based programs “...might be at the cost of losing social-psychological thinking about complex, liquid, and changing social and cultural conditions” (p. 41). Johnson, Whitfield, \& Grohe (2011) discuss problem-based learning noting its applicability to social work because of “...the nature of "real world" problems that occur and the solutions that need to be obtained to meet the client's multiple information needs in solving problems or finding resolutions to situations” (p. 8).

Some writers, such as Lewis (2003), have expressed concern that research is predominantly the enclave of academics and that all stakeholders need to be involved (p. 580). Wheeler and Goodman (2007) echo Lewis's concerns noting the importance of information literacy skills and continuing education for health and mental health social workers so that they can be "...involved in the development of the very evidence that is increasingly driving the decision making and resource allocations in health and mental care” (p. 236). Mirabito (2012) examines the constantly changing and complex work environment that social workers find themselves in and advocates for research partnerships between academic and field educators in order to ensure that academic curricula reflect social work practice in agencies (p. 245).

\section{INFORMATION LITERACY AND STUDENTS AND FACULTY}

The foundations of research skills are laid during professional training. Silfen and Zgoda (2008) reviewed the literature and found that little had been published about social work students and their information literacy needs. They note that the rise of evidence-based practice in social work has increased the importance of information literacy instruction for social work students and requires more attention from librarians in the literature (p. 104). Weetman DaCosta (2010) found 
that material pertaining to information literacy tends to be published in the professional literature for librarians and that “.... where articles were found in mainstream educational journals, most were written by library and information professionals” (p. 204). Lampert (2005) notes that “...specific recommendations and successful strategies for infusing subject specific information literacy skills into graduate studies are not prevalent in information literacy literature” (p. 7). Bellard (2007) finds that information literacy instruction for graduate students is often not incorporated into the curricula and “...remains sporadic at best and offered mainly in a variety of supplemental venues (e.g., online tutorials, assignment related instruction workshops, orientations)” (p. 495). Howard, McMillen, and Pollio (2003) believe that social work schools have not spent enough time “...teaching students the knowledge and skills they need to identify and effectively search the many available sources of practice-relevant information” (p. 19). The authors note that this may be due to inadequate training in this area for faculty members themselves and warn that "...Continued neglect of didactic efforts in this area will seriously hinder efforts to promote evidence-based practice” (p. 19). Lampert (2005) states:

When the current lack of entry-level graduate student information literacy skills is combined with the paucity of higher cognitive skills often displayed in student writing of literature reviews, the critical need for collaboration between librarians and discipline faculty becomes clear. This situation calls for the incorporation of information literacy skills training into graduate curriculum (p. 7).

Bingham, Wirjapranata and Chinnery (2016) describe a collaborative program developed by faculty and information professionals at the University of Auckland which “....aimed to cultivate third-year social work students' understanding of the research-practice nexus by actively inducting them into the use of EBP and relevant IL skills prior to their first practicum” (p. 202). In their concluding remarks, the authors strongly advocate for the integration of both in field work and courses, noting that this "....would embed the importance of the research-practice connection across the curriculum more forcefully and facilitate the development of more information literature EBP practitioners” (p. 209).

Bury describes a survey research study that “...investigates the information literacy (IL) instruction practices, attitudes and perceptions of university faculty at York University” (p. 45). This study was conducted across multiple disciplines. Results of the survey showed that faculty were concerned about the information literacy competencies of students, particularly lower-level undergraduates (p. 49) and that they also thought that the research skills of graduate students were not at a desired level (p. 51). A strong majority of faculty were in favour of students receiving information literacy instruction (p. 51) and also supported a collaborative model with librarians for teaching information literacy competencies (p. 53), but Bury notes that her study found that there was not a high rate of integration of information literacy instruction within courses (p. 59). She makes several recommendations including the need for librarians to take a stronger advocacy role in promoting and educating faculty about the benefits of information literacy instruction (p. $60)$.

As noted previously, not much work has been done about social work students and their information literacy needs. Table 1 gives an overview of several studies pertaining to information literacy and MSW students. A review of the literature clearly shows the need for integrating information literacy into social work curricula and for collaboration between faculty and librarians, librarians and students, and librarians and social work practitioners so that social workers can be effective researchers and practitioners. 
Table 1: Summaries of some recent information literacy studies with social work students and faculty

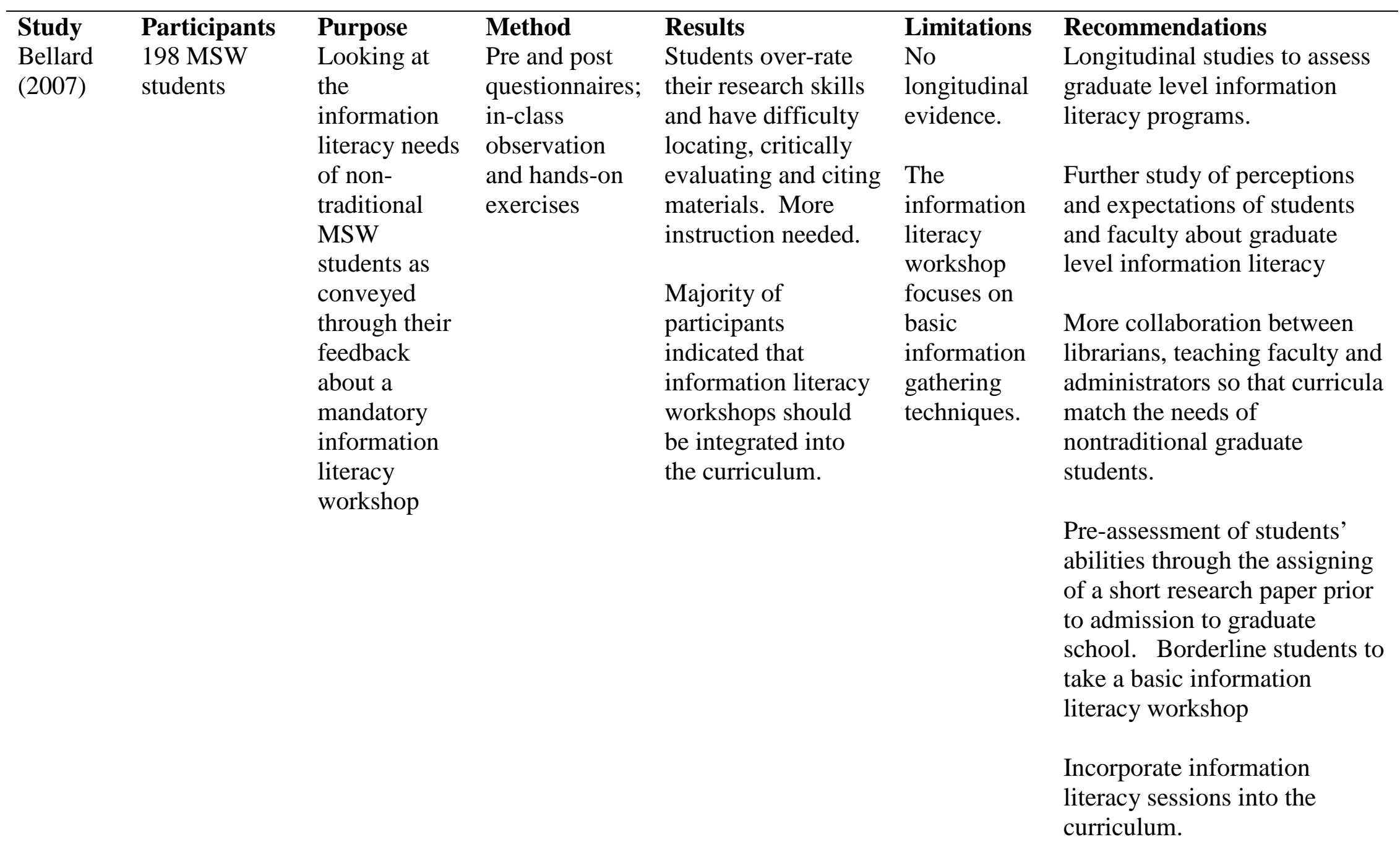


Table 1: Summaries of some recent information literacy studies with social work students and faculty

\begin{tabular}{|c|c|c|c|c|c|c|}
\hline $\begin{array}{l}\text { Study } \\
\text { Brustman } \\
\text { et al. } \\
\text { (2007) }\end{array}$ & $\begin{array}{l}\text { Participants } \\
104 \text { MSW } \\
\text { students }\end{array}$ & $\begin{array}{l}\text { Purpose } \\
\text { Improve } \\
\text { information } \\
\text { and computer } \\
\text { literacy skills } \\
\text { of MSW } \\
\text { students }\end{array}$ & $\begin{array}{l}\text { Method } \\
\text { Series of } \\
\text { required } \\
\text { workshops } \\
\text { closely tied to } \\
\text { the ACRL } \\
\text { information } \\
\text { literacy } \\
\text { standards done } \\
\text { by University } \\
\text { at Albany } \\
\text { librarians in } \\
\text { collaboration } \\
\text { with faculty in } \\
\text { the School of } \\
\text { Social } \\
\text { Welfare. } \\
\text { Surveys and } \\
\text { assessment } \\
\text { tests } \\
\text { administered } \\
\text { to measure } \\
\text { students' } \\
\text { understanding } \\
\text { and rating of } \\
\text { workshop } \\
\text { content. } \\
\text { Classroom } \\
\text { observations. }\end{array}$ & $\begin{array}{l}\text { Results } \\
\text { Workshops have } \\
\text { made students more } \\
\text { aware of library } \\
\text { resources and } \\
\text { services pertaining } \\
\text { to social welfare and } \\
\text { how to use both } \\
\text { efficiently and } \\
\text { effectively. } \\
\text { Social work students } \\
\text { are now the highest } \\
\text { users of reference } \\
\text { services. }\end{array}$ & $\begin{array}{l}\text { Limitations } \\
\text { Small size of } \\
\text { library } \\
\text { classroom } \\
\text { resulting in } \\
\text { more classes } \\
\text { and heavier } \\
\text { workload for } \\
\text { librarians. } \\
\text { Getting the } \\
\text { students to } \\
\text { take the } \\
\text { classes early } \\
\text { in the MSW } \\
\text { program. }\end{array}$ & $\begin{array}{l}\text { Recommendations } \\
\text { More promotion of the } \\
\text { workshops by librarians and } \\
\text { faculty } \\
\text { Use a database to track student } \\
\text { completion of the workshops. } \\
\text { Develop a WebCT version of } \\
\text { the Social Welfare Research } \\
\text { Seminar } \\
\text { Expand the study to other } \\
\text { institutions. } \\
\text { Emphasize the strengths and } \\
\text { differences of social welfare } \\
\text { resources and clearly outline } \\
\text { the library's interlibrary loan } \\
\text { process. }\end{array}$ \\
\hline
\end{tabular}


Table 1: Summaries of some recent information literacy studies with social work students and faculty

\begin{tabular}{|c|c|c|c|c|c|c|}
\hline $\begin{array}{l}\text { Study } \\
\text { Ismail } \\
(2009)\end{array}$ & $\begin{array}{l}\text { Participants } \\
100 \text { traditional } \\
\text { and } \\
\text { nontraditional } \\
\text { students in the } \\
\text { MSW } \\
\text { program at } \\
\text { Marywood } \\
\text { University } \\
\text { comprising of } \\
55 \text { weekend } \\
\text { students; } 7 \\
\text { part-time; } 16 \\
\text { full-time; and } \\
22 \text { satellite } \\
\text { students }\end{array}$ & $\begin{array}{l}\text { Purpose } \\
\text { To get } \\
\text { feedback } \\
\text { from } \\
\text { currently } \\
\text { enrolled } \\
\text { traditional } \\
\text { and } \\
\text { nontraditional } \\
\text { students } \\
\text { about their } \\
\text { library use } \\
\text { and needs } \\
\text { and to } \\
\text { compare } \\
\text { same. }\end{array}$ & $\begin{array}{l}\text { Method } \\
\text { Conducted a } \\
\text { survey, } \\
\text { available } \\
\text { online and in } \\
\text { print which } \\
\text { included open- } \\
\text { ended } \\
\text { questions, } \\
\text { multiple } \\
\text { choice } \\
\text { questions and } \\
\text { rating scales. } \\
\text { Survey } \\
\text { gathered } \\
\text { demographic } \\
\text { information } \\
\text { and feedback } \\
\text { about student } \\
\text { needs, use and } \\
\text { satisfaction } \\
\text { regarding } \\
\text { library } \\
\text { services and } \\
\text { resources. }\end{array}$ & $\begin{array}{l}\text { Results } \\
\text { Additional/improved } \\
\text { assistance needed } \\
\text { for nontraditional } \\
\text { students including } \\
\text { weekend assistance. } \\
\text { Nontraditional } \\
\text { MSW students have } \\
\text { specific library } \\
\text { needs that may } \\
\text { differ from other } \\
\text { students. } \\
\text { Reference e- } \\
\text { mail/chat service } \\
\text { was the least used } \\
\text { resource. }\end{array}$ & $\begin{array}{l}\text { Limitations } \\
\text { Low } \\
\text { response rate } \\
\text { to survey. }\end{array}$ & $\begin{array}{l}\text { Recommendations } \\
\text { Follow-up study of } \\
\text { nontraditional students } \\
\text { consisting of focus groups } \\
\text { and/or a survey to gain more } \\
\text { insight into their preferences } \\
\text { for seeking library assistance } \\
\text { and the impact of student } \\
\text { demographics on those } \\
\text { preferences. } \\
\text { Create a separate gateway for } \\
\text { remote and/or nontraditional } \\
\text { students. } \\
\text { Librarians need to organize } \\
\text { formal library instruction } \\
\text { sessions for satellite students } \\
\text { and explore other options for } \\
\text { providing library assistance. }\end{array}$ \\
\hline
\end{tabular}


Table 1: Summaries of some recent information literacy studies with social work students and faculty

\begin{tabular}{|c|c|c|c|c|c|c|}
\hline $\begin{array}{l}\text { Study } \\
\text { Johnson, } \\
\text { Whitfield } \\
\text { \& Grohe } \\
\text { (2011) }\end{array}$ & $\begin{array}{l}\text { Participants } \\
10 \text { faculty } \\
\text { participants } \\
\text { from a variety } \\
\text { of disciplines. } \\
\text { One of the } \\
\text { faculty } \\
\text { participants } \\
\text { then } \\
\text { incorporated } \\
\text { what he had } \\
\text { learned into } \\
\text { the syllabus } \\
\text { for an MSW } \\
\text { course. }\end{array}$ & $\begin{array}{l}\text { Purpose } \\
\text { To show the } \\
\text { benefits of } \\
\text { collaboration } \\
\text { between } \\
\text { librarians and } \\
\text { faculty } \\
\text { members for } \\
\text { improving } \\
\text { students' } \\
\text { information } \\
\text { literacy skills. }\end{array}$ & $\begin{array}{l}\text { Method } \\
\text { Program with } \\
\text { three phases: } \\
\text { a) Workshop } \\
\text { about the } \\
\text { ACRL } \\
\text { guidelines and } \\
\text { information } \\
\text { literacy } \\
\text { b) } \\
\text { Collaboration } \\
\text { and then a } \\
\text { midterm } \\
\text { presentation } \\
\text { by librarians } \\
\text { and faculty } \\
\text { c) Teaching a } \\
\text { class using the } \\
\text { improved } \\
\text { syllabus and } \\
\text { the final } \\
\text { presentation } \\
\text { A pre- and } \\
\text { posttest were } \\
\text { given to get } \\
\text { baseline } \\
\text { measurements } \\
\text { for students' } \\
\text { information } \\
\text { literacy-related } \\
\text { knowledge. }\end{array}$ & $\begin{array}{l}\text { Results } \\
\text { Noticeable } \\
\text { improvement in the } \\
\text { quality of the } \\
\text { students' papers. } \\
\text { Study shows the } \\
\text { positive impact of } \\
\text { collaboration } \\
\text { between librarians } \\
\text { and faculty for both } \\
\text { the faculty and the } \\
\text { students }\end{array}$ & $\begin{array}{l}\text { Limitations } \\
\text { Small } \\
\text { sample size. }\end{array}$ & $\begin{array}{l}\text { Recommendations } \\
\text { Increase sample size and have } \\
\text { a more diverse population. } \\
\text { More content in future for } \\
\text { librarian participants. } \\
\text { Use this study as the basis for } \\
\text { future research on information } \\
\text { literacy collaborations between } \\
\text { faculty and librarians. }\end{array}$ \\
\hline
\end{tabular}


Table 1: Summaries of some recent information literacy studies with social work students and faculty

\begin{tabular}{|c|c|c|c|c|c|c|}
\hline Study & Participants & Purpose & Method & Results & Limitations & Recommendations \\
\hline $\begin{array}{l}\text { Johnston } \\
\text { (2010) }\end{array}$ & $\begin{array}{l}100 \text { first year } \\
\text { Social Work } \\
\text { students (on } \\
\text { and off } \\
\text { campus) }\end{array}$ & $\begin{array}{l}\text { To provide } \\
\text { the students } \\
\text { with } \\
\text { information } \\
\text { literacy and } \\
\text { research } \\
\text { skills through } \\
\text { an online } \\
\text { module set up } \\
\text { in } \\
\text { Blackboard } \\
\text { and to assess } \\
\text { the efficacy } \\
\text { of the same. }\end{array}$ & $\begin{array}{l}\text { Participation } \\
\text { in a } \\
\text { compulsory } \\
\text { online } \\
\text { information } \\
\text { literacy } \\
\text { module and } \\
\text { evaluation of } \\
\text { the same } \\
\text { through a } \\
\text { survey; focus } \\
\text { groups; } \\
\text { observations } \\
\text { and task } \\
\text { results. }\end{array}$ & $\begin{array}{l}\text { Majority of students } \\
\text { liked and used the } \\
\text { tutorial. } \\
\text { They learned new } \\
\text { techniques and skills } \\
\text { for their } \\
\text { assignments; could } \\
\text { complete it at their } \\
\text { convenience; and } \\
\text { thought that the } \\
\text { quality of their } \\
\text { assignments was } \\
\text { improved by it. }\end{array}$ & $\begin{array}{l}\text { Only } 25 \\
\text { students out } \\
\text { of } 100 \\
\text { completed } \\
\text { the survey - } \\
13 \text { on- } \\
\text { campus } \\
\text { students and } \\
12 \text { off- } \\
\text { campus). }\end{array}$ & $\begin{array}{l}\text { Develop and support the } \\
\text { online information literacy } \\
\text { tutorial. } \\
\text { Build information literacy } \\
\text { content into the social work } \\
\text { program. } \\
\text { Have face-to-face training } \\
\text { available for those who want } \\
\text { it. } \\
\text { Further assess the } \\
\text { effectiveness of the module. } \\
\text { Continue to develop } \\
\text { information literacy skills for } \\
\text { all disciplines. }\end{array}$ \\
\hline
\end{tabular}


Table 1: Summaries of some recent information literacy studies with social work students and faculty

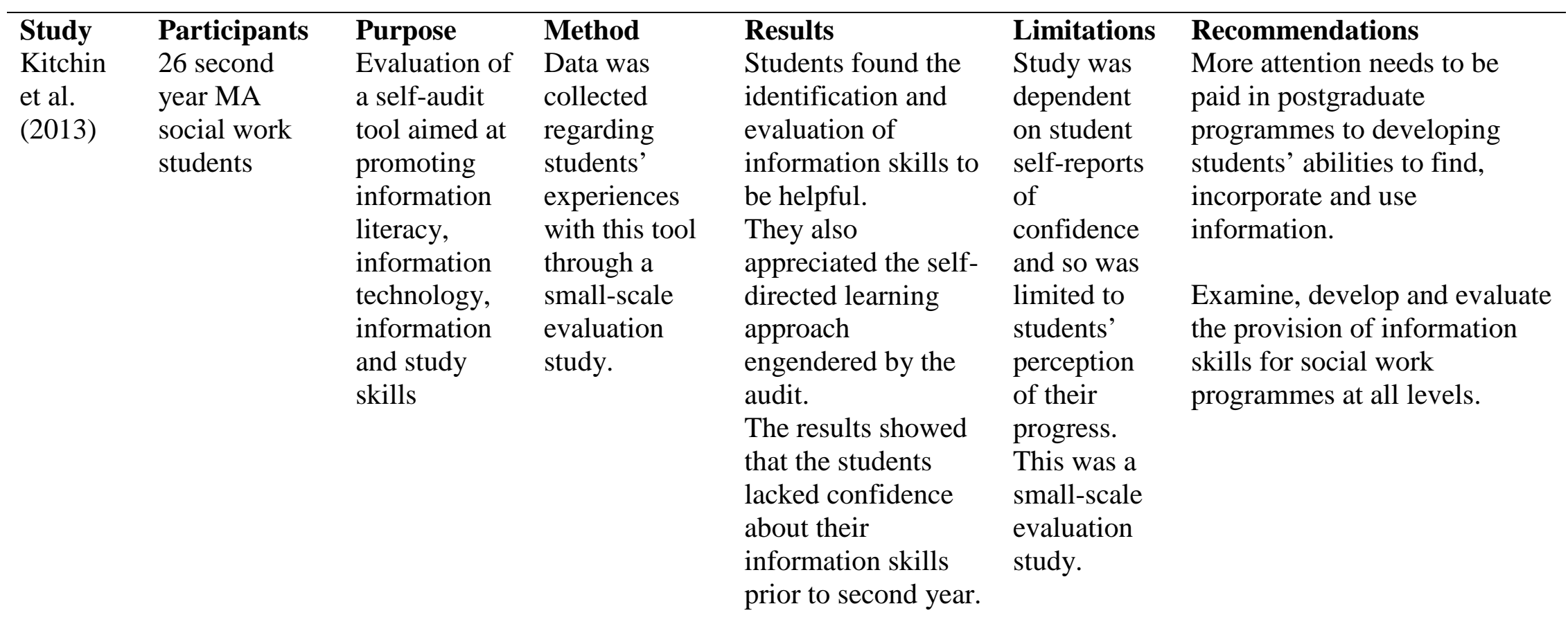


Table 1: Summaries of some recent information literacy studies with social work students and faculty

\begin{tabular}{|c|c|c|c|c|c|c|}
\hline $\begin{array}{l}\text { Study } \\
\text { Silfen et } \\
\text { al. (2008) }\end{array}$ & $\begin{array}{l}\text { Participants } \\
55 \text { MSW } \\
\text { students at } \\
\text { Boston } \\
\text { College }\end{array}$ & $\begin{array}{l}\text { Purpose } \\
\text { To use a } \\
\text { citation study } \\
\text { to identify the } \\
\text { information } \\
\text { literacy needs } \\
\text { of graduate } \\
\text { social work } \\
\text { students and } \\
\text { the role that } \\
\text { librarians can } \\
\text { play in } \\
\text { promoting } \\
\text { evidence- } \\
\text { based } \\
\text { practice. }\end{array}$ & $\begin{array}{l}\text { Method } \\
\text { Small study of } \\
\text { journal } \\
\text { citations in } \\
\text { graduate social } \\
\text { work students' } \\
\text { reference lists } \\
\text { for a required } \\
\text { paper to } \\
\text { determine the } \\
\text { quality of their } \\
\text { sources. }\end{array}$ & $\begin{array}{l}\text { Results } \\
\text { Students need } \\
\text { instruction that } \\
\text { focuses on evidence- } \\
\text { based searching } \\
\text { skills and that will } \\
\text { help them to find } \\
\text { peer-reviewed } \\
\text { articles and sources } \\
\text { that are research- } \\
\text { based. }\end{array}$ & $\begin{array}{l}\text { Limitations } \\
\text { Correlational } \\
\text { analyses } \\
\text { were limited } \\
\text { - additional } \\
\text { research } \\
\text { needs to be } \\
\text { done. } \\
\text { Small } \\
\text { number of } \\
\text { participants. }\end{array}$ & $\begin{array}{l}\text { Recommendations } \\
\text { Increase the number of } \\
\text { participants and citations } \\
\text { studied. } \\
\text { Have a control group for the } \\
\text { next study. } \\
\text { Spend less time on the } \\
\text { mechanics of searching } \\
\text { databases and more time } \\
\text { focusing on the retrieval of } \\
\text { high-quality information. }\end{array}$ \\
\hline
\end{tabular}


Table 1: Summaries of some recent information literacy studies with social work students and faculty

\begin{tabular}{|c|c|c|c|c|c|c|}
\hline $\begin{array}{l}\text { Study } \\
\text { Sizemore } \\
\text { et al. } \\
\text { (2008) }\end{array}$ & $\begin{array}{l}\text { Participants } \\
\text { Undergraduate } \\
\text { social work } \\
\text { students - no } \\
\text { number given. }\end{array}$ & $\begin{array}{l}\text { Purpose } \\
\text { Pilot project } \\
\text { using } \\
\text { constructivist } \\
\text { learning } \\
\text { theory to } \\
\text { teach } \\
\text { research } \\
\text { skills to } \\
\text { social work } \\
\text { students who } \\
\text { were looking } \\
\text { at social } \\
\text { policy } \\
\text { responses to } \\
\text { social } \\
\text { problems. }\end{array}$ & $\begin{array}{l}\text { Method } \\
\text { Increasingly } \\
\text { focused } \\
\text { instruction } \\
\text { moved from } \\
\text { formal class } \\
\text { group } \\
\text { meetings to } \\
\text { small groups } \\
\text { of students to } \\
\text { individual } \\
\text { students. } \\
\text { Collaboration } \\
\text { with faculty on } \\
\text { improving } \\
\text { assignments } \\
\text { and learning } \\
\text { outcomes. }\end{array}$ & $\begin{array}{l}\text { Results } \\
\text { Qualitative evidence } \\
\text { indicates positive } \\
\text { changes in students' } \\
\text { experiences with the } \\
\text { research process and } \\
\text { knowledge related to } \\
\text { the course content. }\end{array}$ & $\begin{array}{l}\text { Limitations } \\
\text { No data } \\
\text { specified. }\end{array}$ & $\begin{array}{l}\text { Recommendations } \\
\text { Incorporate the use of Web } \\
2.0 \text { tools in order to } \\
\text { connect with students } \\
\text { through a variety of } \\
\text { resources. } \\
\text { Combine this with face-to- } \\
\text { face contact with } \\
\text { librarians. }\end{array}$ \\
\hline
\end{tabular}




\section{SOCIAL WORK AT THE UNIVERSITY OF WINDSOR}

The University of Windsor is a mid-sized university in the City of Windsor in southern Ontario, Canada and is very close to the Windsor-Detroit border. The University has a wide range of undergraduate and graduate programs containing more than 15,000 full and part time students. The School of Social Work at the University of Windsor is a dynamic and thriving institution, offering several BSW and MSW program options. The Advanced Standing MSW program is one year in duration and is for students who have an Honours BSW degree. The Regular Track MSW program takes two years of full-time study to complete and is for students with a four-year Honours degree in a related social science discipline or helping profession. The School of Social Work has also developed an Off-Campus MSW for Working Professionals program with Regular and Advanced Tracks. Another exciting development is the MSW/JD program. This is a joint degree program with the Faculty of Law that allows students to attain a Juris Doctor and an MSW degree in three years if they have a BSW degree and in four years if they have an Honours degree in a related field. The School of Social Work also has a PhD program with a focus on civic engagement.

The School of Social Work at the University of Windsor has been very supportive of library services and resources. The Social Work librarian has office space in the School of Social Work and spends one full day a week at the School providing research help to students and faculty. She provides information literacy sessions and also goes to Mississauga and Oshawa with the instructors and coordinators for the MSW Working Professionals Program to participate in orientation sessions for new students. She serves as the library representative on the School of Social Work's Council and has a web page on the School of Social Work's website.

\section{PURPOSE OF THE STUDY}

The purpose of this study was to examine data pertaining to the information literacy levels and needs of graduate students in social work at the University of Windsor. The quantitative data was collected at the very beginning of the semester for each program, in order to ascertain the students' knowledge, abilities and experience with information literacy at the start of their graduate studies. Participants in the study volunteered to complete a quantitative questionnaire that included supplementary open-ended questions. Some students also took part in semistructured follow-up interviews which included observation of the participants' behavior whilst completing specific tasks.

\section{METHODOLOGY}

This study examined the information literacy needs and levels of 44 social work graduate students from a total sample of 201 graduate students by using a quantitative questionnaire that included supplementary open-ended questions (Appendix A) (Magliaro, 2011). The quantitative component consisted of the adapted quantitative instrument called "The Beile Test of Information Literacy for Education” (B-TILED) (Beile O’Neil, 2005), which is used to measure a pre-service student's 
(student teacher candidates in-training) IL (information literacy) skills. Questions \#7,8,10, $12,13,15,18,19,21,23,24$, and 26 were slightly modified in order to reflect Canadian and relevant social work content as well as "to target appropriate standards, performance indicators, and outcomes” (Magliaro, 2011, p.64). As IL encompasses components that go beyond what B-TILED is intended to measure, the instrument was modified to measure IL needs of Master of Social Work students. It was also extended through the use of supplementary, open-ended questions based on the Davis, Bagozzi, and Warshaw (1989) Technology Acceptance Model (TAM). TAM is a particularly useful model for studying the IL and information competency of graduate students, because it utilizes a behavioral component to explain the end-user's behaviours. It should be noted that the main assumption behind TAM is that specific beliefs (i.e., perceived usefulness and perceived ease of use) are primary determinants for the adoption of information technology and information systems (IT/IS) (Lu, Yu, Lio, \& Yao, 2003). Perceived usefulness is described as the extent to which one believes that utilizing the system will improve one's performance, whereas perceived ease of use reflects the belief that utilizing the system will be effortless (Davis et al., 1989; Venkatesh \& Davis, 2000). Thus, one of the key goals of TAM is to measure the impact of external variables on internal beliefs, attitudes, and intentions (Davis et al., 1989; Lu, Yu, Lio, \& Yao, 2003). Based on the modified B-TILED and extended TAM, the survey research questions were formulated encompassing quantitative questionnaire that included supplementary openended questions.

Part 1A: Quantitative Research Question:

a. Which graduate profile variable best predicts graduate students’ IL?

Part 1B: Qualitative Research Question:

b. How do graduate students perceive the usefulness and ease of use of library services?

\section{RESULTS}

This study examined the IL needs of Master of Social Work students through the use of a quantitative questionnaire that included supplementary open-ended questions. The questionnaire consisted of three parts: (i) questions geared towards establishing a profile of a graduate student; (ii) modified B-TILED instrument (Beile O'Neil, 2005); and (iii) open-ended questions (Technology Acceptance Model [TAM], Davis et al., 1989). The first part of the survey encompassed 12 questions, capturing the profile variables of various graduate students. The second section focused on questions related to the students' perceived ability to search library databases and the Internet to find information. It also looked at students' past experiences with library instruction. The last part of the survey included the TAM open-ended questions. This part explored "Usefulness and Ease of use" by requiring responses regarding "Library Instructions, Library Experience Instructional Needs and Software Usage”.

The original criterion-related validity of the survey was noted by comparing the results on a 22item B-TILED written test with the original Morner's (1993) 8-item in library test. The Cronbach's alpha for Master of Social Work modified B-TILED survey was .658. A total of 44 social work graduate students (21.9\%) out of 201 completed the survey. Thirty-nine were female (88.6\%), 41 (93.2\%) were full time students and 23 (52.3\%) were first year students. Thirty (68.2\%) graduate students were enrolled in major course work and a special research project. Seventy-five percent of the students were between 20 and 29 years of age. A total of 23 (52.3\%) graduate students had taken less than 6 courses; had completed a Bachelor of Arts degree; had participated in a library 
tour and had in-class library instruction. There were no international graduate students and 84.09\% indicated that English was their first language (see Appendix B Table 1a). However, the majority of students (79.5\%) did not have one-to-one instruction with a librarian at the very beginning of semester. In addition, the majority of students (88.6\%) noted that graduate students need instruction on how to use library information resources in their subject areas (see Appendix B Table 1a \& Table 1b).

After performing seven one-way analyses of variance (ANOVA) for significance at the .05 confidence level, there was a significant difference $F(1,42)=4.710, \mathrm{p}<.05$ between those participants who were in their first year of study $(M=12.57)$ and those who were in their second year of study $(M=14.67)$, as well as those students who had completed less than six courses $(M=12.57)$ and those who had completed more than six courses $(M=14.67)$. In addition, there was a significant difference $F(1,42)=6.692, \mathrm{p}<.05$ between those participants whose last degree was a Bachelor of Arts $(M=14.47)$ and a Bachelor of Social Work $(M=12.29)$ (see Appendix B -Table 1a \& 2a).

Part 2 of the modified B-TIELD survey consisted of six questions about the graduate students' self-perceived ability to do electronic searches and about their past undergraduate/graduate experiences with library instruction at their current institution. On a scale of 1 to 5 , the majority of students rated themselves as a 4 out of 5 in terms of their ability to search the library databases and the Internet (Appendix B - Table 1b). With regard to students' past undergraduate/graduate experiences with library instruction at their current institution, after performing five one-way analysis of variance (ANOVA) for significance at the .05 confidence level, there were a significant difference $F(1,42)=6.133, \mathrm{p}<.05$ between those students who had taken a library tour $(M=14.70)$ and those who did not $(M=12.33)$ participate. There was also a significant difference $F(1,42)=4.116, \mathrm{p}<.05$ between those students who had library instruction sessions $(M=14.65)$ and those who did not receive such instruction $(M=12.67)$ (see Appendix B Table $1 b$ \& 2b)

Part 3 of the survey contained open-ended questions on the usefulness and ease of use of library services. The participants provided feedback for the following three elements: (i) the perceived usefulness of library instruction at the undergraduate and graduate levels; (ii) the graduate students' need for instruction on the use of library resources and services; and (iii) the use of specific library resources. With regard to perceived usefulness of library instruction, 10 students (22.7\%) had never received undergraduate library instruction while 21 students (47.8\%) had never received graduate library instruction. A total of 26 graduate students (59\%) identified themselves as moderate users of academic library resources and services. However, a large majority of $88 \%(\mathrm{~N}=39)$ students indicated that graduate students need instruction on how to use library information resources in their subject areas. They had mostly used Scholars Portal $(\mathrm{N}=24)$ but had not used RefWorks $(\mathrm{N}=38)$ nor Foxy Leddy $(\mathrm{N}=42)$. As a point of clarification, RefWorks is a bibliographic citation management tool and Foxy Leddy allowed library patrons to search several library resources at one time. After performing one-way analysis of variance (ANOVA) for significance at the .05 confidence level, there was a significant difference $F(1,41)=4.992$, $\mathrm{p}<.05$ between those participants who found library resources easy to use and accessible $(M=14.43)$ and those who did not find this to be the case $(M=12.13)$ (Appendix B - Table 3a and Table 3b). 


\section{ANALYSIS OF THE STUDY}

This data analysis provides a more holistic presentation of social work graduate students' IL needs. Magliaro (2011) further developed the B-TILED survey to accommodate 10 graduate departments including social work (Appendix A). The responses to the quantitative research question - Which graduate profile variable best predicts graduate students' IL ?- showed significant differences for "year of study", “\# of courses completed" and "last degree completed”. The first year graduate students who are entering graduate programs may come from a variety of institutions and so may have a range of experiences or lack thereof with information literacy instruction. Students who completed more than 6 courses (some might be at the thesis stage) and had Bachelor of Arts degrees did have higher IL results. Responses to the qualitative research question - How do graduate students perceive usefulness and ease of use of library services? - showed statistical significance for "library tour" and "library instruction" and "ease of use". This indicates the necessity for providing such services on an ongoing basis and the importance of targeting such services to entry level graduate students.

\section{SURVEY LIMITATIONS}

The demographic data gathered did not include information about the institutions at which the graduate students completed their previous degrees. So it is not clear as to which institutions provided the social work graduate students with library instruction. Therefore, it is necessary to provide information literacy instruction at the start and throughout the graduate program. Future surveys should include more specific demographic information about the social work students and should specify which of the four main streams they are pursuing (Advanced Standing MSW OnCampus; Regular Track MSW On-Campus; Advanced Standing MSW for Working Professionals Off-Campus; and Regular Track MSW for Working Professionals Off-Campus). Data from the distance education MSW Working Professionals Program was not collected.

Another limitation is that the B-TILED survey might not reflect the full breadth of skills and knowledge expected of graduate students (Beile O’Neil, 2005). For example, Standard Four was not included because it was not conducive to the multiple-choice format since it pertains to group work. Future surveys should include the updated ACRL standards. Information gleaned from IQAP reviews and Social Work program outcomes can help to develop a more comprehensive survey. Social work focus group meetings with graduate students, faculty and librarians would also be helpful.

\section{CONCLUSION}

There is much to be gained from this study. Indeed, Magliaro’s (2011) original dissertation, which is the basis for this paper, has already been referenced in three recent doctoral dissertations (Ayoub. 2016; Bishop, 2015; Dumouchel, 2017). Our review of the literature has indicated that very few projects of this nature have been done with social work students. So this research will not only provide information to our immediate campus community about the information literacy levels and needs of graduate students in social work, but it also serves as a first step towards developing more comprehensive information literacy assessment surveys. Analysis of the data and 
conclusions gleaned from this study may lead to recommendations regarding the design of discipline-specific program instruction or workshops focused on increasing information literacy levels of social work graduate students. The ultimate goal would be to revise and modify the current instrumentation, so that future studies of a similar nature can better analyse and serve the information literacy needs of social work graduate students. It is clear from this study that providing at least one standardized mandatory information literacy instruction session at the beginning of a student's graduate career as well as compulsory subject-specific information literacy instruction throughout - face-to-face, online and/or blended - would benefit many graduate students. Finally, this data analysis serves as a model study that can be implemented at other universities, particularly those that are part of the Ontario Council of University Libraries (OCUL) consortium, such as the University of Windsor.

\section{References}

Association of College \& Research Libraries (2000). Information literacy competency standards for higher education. Retrieved from:

http://www.ala.org/ala/mgrps/divs/acrl/standards/informationliteracycompetency.cfm

Association of College \& Research Libraries (2016). Framework for information literacy for higher education. Retrieved from: http://www.ala.org/acrl/standards/ilframework

Association of College \& Research Libraries (2015). Introduction for Faculty and Administrators). Retrieved from: http://www.ala.org/acrl/standards/ilframeworkapps\#introfaculty

Ayoub, Y. (2016). An investigation of information literacy of international graduate students: skills, challenges, and needs (Unpublished doctoral dissertation). University of Central Florida, Orlando, FL.

Beile O'Neil, P. M. (2005). Development and validation of the Beile Test of Information Literacy for Education (B-TILED) (Doctoral dissertation). Retrieved from ProQuest Dissertations \& Theses Global database. (Order No. 3193465).

Bellard, E.M. (2007). Information literacy needs of nontraditional graduate students in social work. Research Strategies, 20(4), 494-505. doi: 10.1016/j.resstr.2006.12.019

Bingham, T.J., \& Wirjapranata, J., \& Chinnery, Shirley-Ann. (2016). Merging information literacy and evidence-based practice for social work students. New Library World, 117(3-4), 201-213. http://dx.doi.org/10.1108/NLW-09-2015-0067

Bishop, C.G. (2015). An investigation of the information practices of education doctoral students (Unpublished doctoral dissertation). University of Central Florida, Orlando, FL.

Bradley, C. (2013). Information literacy in the programmatic university accreditation standards of select professions in Canada, the United States, the United Kingdom and Australia. Journal of Information Literacy, 7(1), 44-68. http://dx.doi.org/10.11645/7.1.1785

Brustman, M.J., \& Bernnard, D. (2007). Information literacy for social workers: University at Albany Libraries prepare MSW students for research and practice. Communications in Information Literacy, 1(2), 89-101.

Bury, S. (2011). Faculty attitudes, perceptions and experiences of information literacy: a study across multiple disciplines at York University, Canada. Journal of Information Literacy, 5(1), 45-64. http://dx.doi.org/10.11645/5.1.1513

Catalano, A.J. (2010). Using ACRL standards to assess the information literacy of graduate 
students in an Education program. Evidence Based Library and Information Practice, 5(4), 21-38. http://dx.doi.org/10.18438/B8V62B

Dumouchel, G. (2017). Les compétences informationnelles des futurs enseignants québécois sur le Web. Université de Montréal. Retrieved from https://papyrus.bib.umontreal.ca/xmlui/handle/1866/18372

Fontno, T.J., \& Brown, D.N. (2015). Putting information literacy in the students' hands: the elementary learning centers approach applied to instruction in higher education. $C \& R L$ News,76(2), 92-97.

Gibbs, L., \& Gambrill, E. (2002). Evidence-based practice: counterarguments to objections. Research on Social Work Practice, 12(3), 452-476. doi: 10.1177/1049731502012003007

Gordon, L., \& Bartoli, E. (2012). Using discipline-based professional association standards for information literacy integration: a review and case study. Behavioral and Social Sciences Librarian, 31(1), 23-38. http://dx.doi.org/10.1080/01639269.2012.657518

Gullikson, S. (2006). Faculty perceptions of ACRL’s Information Literacy Competency Standards for Higher Education. Journal of Academic Librarianship, 32(6), 583-592. doi: 10.1016/j.acalib.2006.06.001

Herz, M., \& Johansson, T. (2011). Critical social work - considerations and suggestions. Critical Social Work, 12(1), 28-45.

Howard, M.O., \& McMillen, C.J., \& Pollio, D.E. (2003). Teaching evidence-based practice: toward a new paradigm for social work education. Research on Social Work Practice, 13(2), 234-259. doi: 10.1177/1049731502250404

Ismail, L. (2010). Revelations of an off-campus user group: library use and needs of faculty and students at a satellite graduate social work program. Journal of Library Administration, 50(5-6), 712-736. doi: 10.1080/01930826.2010.488957

Ismail, L. (2009). What they are telling us: library use and needs of traditional and nontraditional students in a graduate social work program. The Journal of Academic Librarianship, 35(6), 555-564.

Johnson, O.J., \& Whitfield, J.S., \& Grohe, B. (2011). Improving social work students' information literacy skills: a faculty and librarian collaboration. Journal on Excellence in College Teaching, 22(3), 5-21.

Johnston, N. (2010). Is an online learning module an effective way to develop information literacy skills? Australian Academic \& Research Libraries, 41(3), 207-218.

Kitchin, S., \& Lampitt, S. (2013). Evaluation of a self-audit tool to support information skills development in postgraduate students. SCONUL Focus 59, 54-59.

Kovach, M., \& Montgomery, H. (2010). What kind of learning? For what purpose? Reflections on a critical adult education approach to online Social Work and Education courses serving Indigenous distance learners. Critical Social Work, 11(1), 27-41.

Lampert, L. (2005). Getting psyched about information literacy: a successful faculty-librarian collaboration for educational psychology and counseling. The Reference Librarian, 43(89), 5-23. doi: 10.1300/J120v43n89_02

Lewis, C. (2003). Preparing the next generation of researchers. Social Work Education: The International Journal, 22(6), 577-587.

Magliaro, Jelena, "Comparing Information Literacy Needs of Graduate Students in Selected Graduate Programs through the Technology Acceptance Model and Affordance Theory" (2011). Electronic Theses and Dissertations. 424. https://scholar.uwindsor.ca/etd/424 
Mirabito, D.M. (2012). Educating a new generation of social workers: challenges and skills needed for contemporary agency-based practice. Clinical Social Work Journal, 40(2), 245-254.

Poole, J.M. (2010). Progressive until graduation? Helping BSW students hold onto antioppressive and critical social work practices. Critical Social Work, 11(2), 2-11.

Saunders, L. (2017). Connecting information literacy and social justice: why and how. Communications in Information Literacy, 11(1), 55-75.

Silfen, K., \& Zgoda, K. (2008). Evidence-based practice and information literacy in social work: an assessment of students' reference lists. Behavioral and Social Sciences Librarian, 27(2), 104-115. doi: 10.1080/01639260802202082

Sizemore, L. et al. (2008). Social policy and constructivism using constructivist learning theory in teaching social work students research skills. The Southeastern Librarian, 56(3), 1720.

Weetman, DaCosta, J. (2010). Is there an information literacy skills gap to be bridged? An examination of faculty perceptions and activities relating to information literacy in the United States and England. College and Research Libraries, 71(3), 203-222.

Wheeler, D.P., \& Goodman, H. (2007). Health and mental health social workers need information literacy skills. Health and Social Work, 32(3), 235-237. 


\section{Appendix A: Part 1: Survey Instrument - for Graduate Students}

This questionnaire aims to compare the information literacy skills of graduate students in the selected graduate programs. The questionnaire is divided into three parts:

Part 1- we ask you to provide background information about yourself.

Part 2- we ask you to indicate the answer that best applies to you.

Part 3- we ask you to elaborate on your experiences with library services.

\section{Part 1: Demographics}

Please complete the following by placing a checkmark $(\sqrt{ })$ in the appropriate spaces:

1. Gender:

2. Student Status:

Male

Full-Time
Female

Part-Time

3. Year of Study: 1

2

3

$4+$

\section{Program of Study - Department:}

(e.g. MA - Psychology, PhD - Education)

5. Program of Study: (use checkmark $\sqrt{ }$ ):

Course work only

Course work and special research project

Course work and thesis

6. Total number of courses currently completed in this programme

7. What is your age range?

$\begin{array}{ll}- & 20-29 \\ - & 30-39 \\ & 40-49 \\ & 50-59 \\ & 60+\end{array}$

8. Are you an international student? YES __ NO

9. Year of completion of your last degree:

Indicate your last completed degree:

10. Start year of your current degree:

11. Do you work or have you worked (in the last 5 years) in a library-related position?

YES NO

12. Is English your first language?

YES

NO 


\section{Part 2: Please circle the answer that best applies to you (only ONE answer)}

1. Overall, on a scale 1-5, where 1 means low ability and $\mathbf{5}$ means high ability, how would you rate your ability to search library databases to find information? (Circle one)

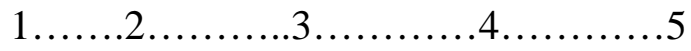

2. Overall, on a scale 1-5, where 1 means low ability and $\mathbf{5}$ means high ability, how would you rate your ability to search the Internet to find information? (Circle one)

1 .......2.............................5

Please indicate whether you have experienced any of the following since you began your studies at the University of Windsor.

3. Have you attended an organized tour of the academic library?
a. Yes
b. No

4. Have you attended a library instruction session held in your classroom?
a. Yes
b. No
c. None was organized.

5. Have you attended a library instruction session held in the academic library?
a. Yes
b. No

6. Have you had one-on-one intensive instruction with a librarian?
a. Yes
b. No

7. Which of the following characteristics best indicates scholarly research? (Circle one)
a. Available in an academic library
b. Indexed by Social Service Abstracts
c. Reviewed by experts for publication
d. Written by university faculty

8. In a graduate course you are examining the topic of 'child development'. You are not familiar with this topic and you want to find a brief history and summary about it from a social work perspective. Which of the following sources would be your first choice to consult?
a. A book on the topic, such as Child development: A case study.
b. A journal article
c. General web site (via Google)
d. A social work encyclopedia, such as Encyclopedia of Child Development

9. Research or periodical databases are designed to include items based on which of the following criteria?
a. Found on the Internet
b. Not found on the Internet
c. Owned by your library
d. Relevant subject matter 
10. Social Service Abstracts is the most appropriate database to use to locate:
a. Social work article citations, publications and documents
b. Social work publications from 1877 to current
c. Full-text social work articles
d. Ontario Ministry of Education Statistics

11. Most research and periodical databases have basic and advanced searching interfaces. Which of the following can be done ONLY in advanced searching? (Circle one)
a. Add Boolean or search connectors between terms
b. Enter multiple search terms
c. Search by keyword
d. Search multiple terms by field

12. Research studies in social work are generally first communicated through (Circle one):

a. Books published by social work associations

b. Social work encyclopedia entries

c. Newsletters of social work associations

d. Professional conferences and journal articles

13. You have been assigned to write a short class paper on effective instruction techniques for explaining child welfare to English as Second Language (ESL) students. Your professor indicated three recent scholarly sources would be sufficient. Which strategy is best to locate items? (Circle one)
a. Search a general database for journal articles
b. Search social work and education databases for journal articles
c. Search the library catalog for books
d. Search the library catalog for encyclopedias

14. Select the set of search terms that best represent the main concepts in the following: "What are the health risks associated with the use of drug therapy for hyperactive students?”
a. Drug therapy, health risks, hyperactivity
b. Drug therapy, health risks, students
c. Drug therapy, hyperactivity, students
d. Drugs, hyperactivity, therapy

15. Select the option that best represents synonyms and related terms for the concept "university students."
a. Universities, adult learners, community colleges...
b. Gen X, students, undergraduates...
c. Graduate students, undergraduate students, post-secondary students...
d. University, adult learners, educational attendees...

16. While researching a paper on character education, you find that it is also sometimes called values education or moral education. You decide to look for information on the subject in a research database, and to save time you write a search statement that includes all three terms. 
Which of the following is the best example to use when you have fairly synonymous terms and it does not matter which of the terms is found in the record?
a. Character and values and moral
b. Character or values or moral
c. Character, values and moral
d. Character, values or moral

17. You are using a research database that uses an asterisk $\left(^{*}\right)$ as its truncation symbol. When you type in read* you would retrieve records that contained which of the following words?
a. Examine, peruse, reader, reading
b. Peruse, read, reader, reading
c. Read, reader, reads, readmit
d. Read, reader, reading, reapply

18. You have a class assignment to investigate how group work impacts student learning. A keyword search in Social Service Abstracts on "group work" has returned over 600 items. To narrow your search, which of the following steps would you perform next?

a. Add 'impacts' as a keyword and combine with 'group work'

b. Add 'student learning' as a keyword and combine with 'group work'

c. Limit search results by date

d. Limit search results by publication type

19. The following citation is for:

Massaro, D. (1991). Broadening the domain of the fuzzy logical model of perception. In H. L. Pick, Jr., P. van den Broek, \& D. C. Knill (Eds.), Cognition: Conceptual and methodological issues (pp. 51-84). Washington, DC: American Psychological Association.
a. A book
b. A chapter in a book
c. A journal article
d. A Social Service Abstracts document

20. Your professor suggested you read a particular article and gave you the following citation: Shayer, M. (2003). Not just Piaget, not just Vygotsky. Learning and Instruction 13(5), 465-485. Which of the following would you type into the library's catalog to locate the actual article?
a. Author search: Shayer
b. Journal title search: Learning and Instruction
c. Journal title search: Not just Piaget, not just Vygotsky
d. Subject search: Piaget and Vygotsky

21. The following item was retrieved from a Social Service Abstracts database search. What kind of source is it?

Title: Public Attitudes towards Multiculturalism and Bilingualism in Canada 
Author(s): Dasko, Donna.

Publication Year: 2003

Abstract: The purpose of this study was to examine Canadian public attitudes toward multiculturalism and bilingualism.

Notes: Presented at the Annual Conference - Canadian and French Perspective on

Diversity (Ottawa, April 10-14, 2003).

Number of Pages: 24
a. A book
b. A book chapter
c. A conference paper
d. A journal article

22. Using this result from an Internet search engine, who is the "owner" of this Web site? State policies on planning, funding, and standards. Does the state have technology requirements for students? http://www.edweek.org/reports/tc98/states/fl.htm
a. Business or commercial entity
b. College or university
c. Other organization
d. State government agency

23. While conducting research on the Canadian legislative system, you find the following story on the Internet:

BMJ 2001; 322:1200 (19 May)

Canada's parliament calls for tighter water standards

Alarmed by growing fears of widespread pollution of drinking water, Canada's parliament has passed a resolution calling for a national law setting out enforceable national standards for water quality.

Forty six people have recently become infected with cryptosporidium in the small farming town of North Battleford, Saskatchewan, and three deaths were at first thought to have been caused by the parasite. The province's chief medical health officer later said that cryptosporidium was not the cause of two of the deaths but may have played a minor part in the third.

(Source: The BMJ is published by BMJ Publishing Group Ltd, a wholly owned subsidiary of the British Medical Association)

Given this, the following action is in order:

a. You can use the story as it is obviously from a reputable news source

b. You decide to investigate the reputation of the publisher by looking at their Web site

c. You decide to investigate the reputation of the publisher by looking at other Web sites

d. You should not use the story because Web information is not always trustworthy

24. Which of the next four sentences may be used as a citation? 
(1) Technology use in the schools is often characterized as a potentially dehumanizing force.

(2) Perhaps the fear that the virtual world may lead to passivity and isolation, at the expense of literal social interaction, is valid.

(3) Certainly, educators must ask which uses of technology result in increased learning and a better quality of life.

(4) To address these issues, Hunter (2005) has proposed that "students should work in groups with the computer peripheral and the teacher acting as a facilitator" (p.25).
a. 1
b. 2
c. 3
d. 4

25. When is it ethical to use the ideas of another person in a research paper?
a. It is never ethical to use someone else's ideas
b. Only if you do not use their exact words
c. Only when you give them credit
d. Only when you receive their permission

26. You are planning conference presentation. Browsing the Internet, you find the report "Child Abuse: Recognize it, Report it, Prevent it” by the Ontario's provincial government. If you distribute 30 copies of the report to the other conference attendees, which of the following copyright choices is the proper action?

a. Permission is not needed as the report is from a government agency.

b. Permission is not needed as the report was found on the Internet.

c. Permission is not needed as you are only distributing 30 copies.

d. Permission to distribute 30 copies of the report must be acquired.

27. You have an assignment that requires you to use course management software to practice setting up a class grade book. Your school has purchased the software and loaded it in the computer lab, but you have a difficult time getting to the lab due to work conflicts. A friend loans you the software and you load it on your computer. Is this legal?
a. No, because this action constitutes a violation of copyright.
b. Yes, because it is already freely available in the lab.
c. Yes, because it is education software and therefore able to be shared.
d. Yes, because your friend owns it and can share as he wants.

28. Browsing a weekly news magazine, you come across an article that discusses the future of space exploration. As you are teaching this topic you decide to make copies of the article and share it with your class. Which of the following concepts makes it legally permissible to reproduce portions of works for educational purposes without permission? 

a. Copyright
b. Fair use
c. Freedom of information
d. Intellectual freedom

\section{Part 3: Please elaborate on your experiences with library services in general.}

Usefulness and Ease of use

1) Library Instructions

How many times have you been given instruction on how to use library resources by librarians?

$\begin{array}{llllll}\begin{array}{l}\text { At the undergraduate } \\ \text { level: }\end{array} & 0 & 1 & 2 & 3+ \\ \text { At the graduate level: } & 0 & 1 & 2 & 3+\end{array}$

2) If you were given library instruction at the undergraduate level:

(a) What kind of instruction did you receive?

(b) Did you find the instruction useful? (Elaborate)

2a) If you were given library instruction at the graduate level:

(a) What kind of instruction did you receive?

(b) Did you find the instruction useful? (Elaborate)

3) Library Experience 
Circle the number that best reflects your experience with academic library resources and services.

1

little experience

(limited use)
2

some experience

(moderate use)
3

extensive experience
(frequent use)

(a) Describe some of the experiences you have had with academic library services and resources:

4) Instructional Needs

(a) Do you think that graduate students need instruction on how to use library information resources in their subject areas?

YES_ NO

Please explain.

(b) Which library services and resources do you need the most help with to meet your graduate student information needs?

(c) What library resources do you use most in your subject area (e.g. WilsonWeb, Scholars Portal, Project Muse, CBCA, etc)?

5) Specific software use:

(a) Explain the purpose of the "Get It" button as in Getit! ?

(b) You click on the "Get It" Gget it! button and receive the following message: "No full-text available.” What do you do next?

(c) Do you use RefWorks - Online Research Management, Writing and Collaboration Tool? 
YES

$\mathrm{NO}$

If yes, for what purpose do you use RefWorks?

(d) Do you use the Foxy Leddy LibX Toolbar - a toolbar that allows you to quickly search the University of Windsor's Library resources?

YES

NO

If yes, for what purpose do you use the Foxy Leddy LibX Toolbar?

(e) Do you find library resources easy to access and use?

YES

$\mathrm{NO}$

If not, please specify some main difficulties you have encountered.

(f) List the ways in which you think library services could be improved to better suit graduate students’ needs.

\section{Thank you!}

\section{Voluntary contact information}

If you wish to participate in a qualitative follow-up study, please leave your name, phone number or email:

Name: Telephone number:

E-mail: 


\section{Appendix B:}

Table 1a

Descriptive Statistics for IL Results for Master of Social Work Students

Part 1A: Modified B-TILED survey: Quantitative Research Questions

\begin{tabular}{|c|c|c|c|c|c|}
\hline Variable & Variable Categories: & $\mathrm{N}$ & $\%$ & $\begin{array}{c}\text { B-TILED } \\
M\end{array}$ & $\begin{array}{c}\text { B-TILED } \\
S D\end{array}$ \\
\hline \multirow[t]{2}{*}{ Gender } & Male & 5 & $11.4 \%$ & 12.60 & 5.771 \\
\hline & Female & 39 & $88.6 \%$ & 13.69 & 3.001 \\
\hline \multirow[t]{2}{*}{ Student Status } & Full-Time & 41 & $93.2 \%$ & 13.61 & 3.434 \\
\hline & Part-Time & 3 & $6.8 \%$ & 13.00 & 2.000 \\
\hline \multirow[t]{2}{*}{ Year of Study } & First Year & 23 & $52.3 \%$ & 12.57 & 3.847 \\
\hline & Second Year & 21 & $47.7 \%$ & 14.67 & 2.309 \\
\hline \multirow{2}{*}{$\begin{array}{l}\text { Program of study } \\
\text { (Master's students only) }\end{array}$} & Course work only & 14 & $31.8 \%$ & 13.43 & 3.817 \\
\hline & $\begin{array}{c}\text { Course work and } \\
\text { special research } \\
\text { project } \\
\text { (Major Paper) }\end{array}$ & 30 & $68.2 \%$ & 13.63 & 3.168 \\
\hline \multirow[t]{4}{*}{ Age Group } & $20-29$ & 33 & $75.00 \%$ & 14.00 & 3.021 \\
\hline & $30-39$ & 5 & $11.36 \%$ & 14.20 & 3.033 \\
\hline & $40-49$ & 4 & $9.09 \%$ & 12.75 & 3.500 \\
\hline & $50-60+$ & 2 & $4.55 \%$ & 6.50 & 2.121 \\
\hline \multirow{2}{*}{$\begin{array}{l}\text { \# of Courses } \\
\text { Completed }\end{array}$} & Less than 6 courses & 23 & $52.3 \%$ & 12.57 & 3.727 \\
\hline & 6 or more courses & 21 & $47.7 \%$ & 14.67 & 2.517 \\
\hline \multirow[t]{2}{*}{ Last Completed Degree } & Bachelor of Arts & 23 & $52.3 \%$ & 14.74 & 2.416 \\
\hline & $\begin{array}{c}\text { Bachelor of Social } \\
\text { Work }\end{array}$ & 21 & $47.7 \%$ & 12.29 & 3.783 \\
\hline English as First & Yes & 37 & $84.09 \%$ & 13.68 & 3.010 \\
\hline Language & $\begin{array}{c}\text { No - EAL (English } \\
\text { as Additional } \\
\text { Language) }\end{array}$ & 7 & $15.91 \%$ & 13.57 & 5.033 \\
\hline Total & & 44 & & 13.57 & 3.344 \\
\hline
\end{tabular}


Table $1 b$

Part 1B: Open-ended TAM questions: Qualitative Research Question

Descriptive Statistics based on the Graduate Student's Past Experience at the Library

Instructions at the Current Institution

\begin{tabular}{|c|c|c|c|c|c|}
\hline Variable & Variable Categories: & $\mathrm{N}$ & $\%$ & $\begin{array}{c}\text { B-TILED } \\
M\end{array}$ & $\begin{array}{c}\text { B-TILED } \\
S D\end{array}$ \\
\hline Ability to search & 2 & 3 & $6.82 \%$ & 12.33 & 1.155 \\
\hline \multirow{3}{*}{ Library Databases } & 3 & 12 & $27.27 \%$ & 12.33 & 4.960 \\
\hline & 4 & 25 & $56.82 \%$ & 14.24 & 2.368 \\
\hline & 5 & 4 & $9.09 \%$ & 14.00 & 3.559 \\
\hline Ability to search the & 2 & 1 & $2.27 \%$ & 11.00 & \\
\hline \multirow{3}{*}{ Internet } & 3 & 5 & $11.36 \%$ & 11.60 & 5.459 \\
\hline & 4 & 22 & $50.00 \%$ & 13.50 & 3.391 \\
\hline & 5 & 16 & $36.36 \%$ & 14.44 & 2.337 \\
\hline \multirow[t]{2}{*}{ Library Tour } & Yes & 23 & $52.3 \%$ & 14.70 & 2.530 \\
\hline & No & 21 & $47.7 \%$ & 12.33 & 3.733 \\
\hline \multirow[t]{3}{*}{ Classroom Instruction } & Yes & 23 & $52.3 \%$ & 13.74 & 3.922 \\
\hline & No & 12 & $27.3 \%$ & 13.17 & 3.215 \\
\hline & None was organized & 9 & $20.5 \%$ & 13.67 & 1.803 \\
\hline \multirow[t]{2}{*}{ Library Instructions } & Yes & 20 & $45.5 \%$ & 14.65 & 2.455 \\
\hline & No & 24 & $54.5 \%$ & 12.67 & 3.749 \\
\hline \multirow[t]{2}{*}{ One-on-one instructions } & Yes & 9 & $20.5 \%$ & 13.89 & 2.315 \\
\hline & No & 35 & $79.5 \%$ & 13.49 & 3.584 \\
\hline \multirow[t]{2}{*}{ Instructional Needs } & Yes & 39 & $88.6 \%$ & 13.54 & 3.417 \\
\hline & No & 5 & $11.4 \%$ & 13.8 & 3.033 \\
\hline Total & & 44 & & 13.57 & 3.344 \\
\hline
\end{tabular}


Table 2a

Part 1A: ANOVA Results for IL Results for Master of Social Work Students

\begin{tabular}{|c|c|c|c|c|}
\hline Variable & $\mathrm{df}$ & MS & $\mathrm{F}$ & Sig. \\
\hline \multirow[t]{2}{*}{ Gender } & 1 & 5.288 & .467 & .498 \\
\hline & 42 & 11.322 & & \\
\hline \multirow[t]{2}{*}{ Student Status } & 1 & 1.039 & .091 & .764 \\
\hline & 42 & 11.423 & & \\
\hline \multirow[t]{2}{*}{ Year of Study } & 1 & 48.477 & 4.710 & $.036^{*}$ \\
\hline & 42 & 10.293 & & \\
\hline \multirow[t]{2}{*}{ Program of study } & 1 & .400 & .035 & .853 \\
\hline & 42 & 11.438 & & \\
\hline \multirow[t]{2}{*}{ \# of Courses Completed } & 1 & 48.477 & 4.710 & $.036^{*}$ \\
\hline & 42 & 10.293 & & \\
\hline \multirow[t]{2}{*}{ Last Completed Degree } & 1 & 66.075 & 6.692 & $.013^{*}$ \\
\hline & 42 & 9.874 & & \\
\hline \multirow[t]{2}{*}{ English as First Language } & 1 & 2.687 & .236 & .630 \\
\hline & 42 & 11.384 & & \\
\hline Total & 43 & 480.795 & & \\
\hline
\end{tabular}

${ }^{*} \mathrm{p}<.05$

Table 2b

Part 1B: ANOVA Results for IL Results for Master of Social Work Students

\begin{tabular}{ccccc}
\hline Variable & $\mathrm{df}$ & $\mathrm{MS}$ & $\mathrm{F}$ & Sig. \\
\hline Library Tour & 1 & 61.259 & 6.133 & $.017^{*}$ \\
& 42 & 9.989 & & .891 \\
\hline Classroom instruction & 2 & 1.347 & .116 & $.049^{*}$ \\
& 41 & 11.661 & & .751 \\
\hline Library Instructions & 1 & 42.912 & 4.116 & .871 \\
& 42 & 10.426 & & \\
\hline One-on-one instructions & 1 & 1.164 & .102 & \\
\hline Instructional Needs & 42 & 11.420 & & \\
\hline Total & 1 & .303 & & \\
\hline
\end{tabular}

${ }^{*} \mathrm{p}<.05$ 
Table 3a

Ease of Use ANOVA Mean results

\begin{tabular}{|c|c|c|c|c|c|}
\hline Variable & Variable Categories: & $\mathrm{N}$ & $\%$ & $\begin{array}{c}\text { B-TILED } \\
M\end{array}$ & $\begin{array}{c}\text { B-TILED } \\
\text { SD }\end{array}$ \\
\hline Ease of Use & Yes & 28 & & 14.43 & 2.741 \\
\hline & No & 15 & & 12.13 & 3.962 \\
\hline Total & & 43 & & 13.63 & 3.344 \\
\hline
\end{tabular}

Table $3 b$

Ease of Use ANOVA results

\begin{tabular}{ccccc}
\hline Variable & df & Mean Square & F & Sig. \\
\hline Ease of Use & 1 & 51.456 & 4.992 & $.031^{*}$ \\
& 41 & 10.307 & & \\
\hline Total & 42 & 480.795 & & \\
\hline
\end{tabular}

$* \mathrm{p}<.05$

Note:

This research was supported by the Social Sciences and Humanities Research Council of Canada.

Acknowledgement: the authors would like to note their sincere gratitude and acknowledgement to Dr. Penny Minton Beile for granting them permission to modify The Beile Test of Information Literacy for Education (B-TILED) and allowing copyright permissions needed for publication.

\section{About the authors}

Dr. Jelena Magliaro’s academic background in computer science, psychology and education has influenced her research interests, focusing on the role of technology use in teaching and learning. Dr. Magliaro works at University of Windsor as a budget analyst.

Sharon Munro is an Information Services librarian at the Leddy Library, University of Windsor. She is the liaison librarian for Social Work and Human Kinetics. In addition to a Master's degree in Library and Information Studies, she also has undergraduate and graduate degrees in Social Work. 